\title{
Zero Tillage Technique with High Yielding Variety for Wheat Cultivation as Compared to Traditional Method of Farmers: Evidences of FLD
}

\author{
Mrinal Verma*, B. D. Singh, Prakash Chandra Gupta and Rajeev Kumar \\ Krishi Vigyan Kendra, Agwanpur, Barh, Patna, Bihar-803214, India \\ *Corresponding author
}

\begin{tabular}{|l|}
\hline Ke y w o r d s \\
Wheat (Triticum \\
aestivum L.), \\
Tillage technique, \\
FLD
\end{tabular}

\section{Introduction}

India is the second largest producer of wheat (Triticum aestivum $\mathrm{L}$.) in the world with an average annual production of $80 \mathrm{Mt}$ (million tons) in recent years (Anonymous, 2011). It accounts for approximately 11.79 per cent of world's wheat production (FAO, 2011). After the Green Revolution, the production of wheat

\section{A B S T R A C T}

The study was conducted in the different Block of Patna district in Bihar under Frontline Demonstration by Krishi Vigyan Kendra, Agwanpur, Barh, Patna through coordinating Institution Bihar Agricultural University, Sabour, Bhgalpur, Bihar. Demonstration with Zero Tillage wheat has shown primarily positive impacts on wheat crop management, particularly through reduced input needs combined with potential yield increase. To evaluate the economics of high yielding variety (HD 1563) and their utilisation in zero tillage to improve income of farmers and agricultural productivity, the utilisation of high yielding variety under frontline demonstration programme was demonstrated and calibrated using the data of a field experiment in Pandarak, Ghoshwari and Barh Block of Patna district. The average yield of high yielding variety (HD 1563) was recorded 34.1 $\mathrm{q} /$ ha over conventional sowing it is $27.9 \mathrm{q} /$ ha by using local variety of wheat. In another case study, the average yield in zero-tillage method was recorded $36.6 \mathrm{q} \mathrm{ha}^{-1}$ over conventional sowing it is $27.4 \mathrm{q} / \mathrm{ha}$ by using local variety of wheat. The average yield of HD 1563 was $34.1 \mathrm{q} / \mathrm{ha}$ and yield of zero tillage technique was $36.6 \mathrm{q} / \mathrm{ha}$. The data collected from the field were analysed and the result of the study in respect of percentage increase in yield in HD 1563 with ZT increased 7.33\% over farmers practice by using HD 1563. The $\mathrm{B}: \mathrm{C}$ ratio was observed higher side by using HD 1563 is 1.6 as compared to conventional method sowing of wheat is 1.4. The $\mathrm{B}$ : $\mathrm{C}$ ratio was observed higher side in zero-tillage method is 1.6 as compared to conventional method sowing of wheat is 1.5 . The finding have clearly established that wheat sowing can be advanced in yield by using HD 1563 over utilisation of local variety of wheat, under zero tillage method it also clearly established that wheat sowing can be advanced in yield over conventional tillage system. 
The greatest demand for wheat in the coming years will have to be met by increasing devotion of land to wheat or increasing yield per unit area. In India, wheat grown on an area of 30.37 million hectare with total production of 90.78 million tonnes making an average yield of 2.99 t/ ha, while in Jharkhand, wheat grown on an area of 1.7 million hectares with total production of 3.36 million tonnes, making an average yield of $1.98 \mathrm{t} / \mathrm{ha}$ (Anonymous, 2015). Among various factors responsible for low yield of wheat crop in the country, sowing time and varietal (genotypic) selection are of primary importance. Wheat is sown in winter and it has its own definite requirements for temperature and light for emergence, growth and flowering (Dabre et al., 1993).

Demonstration with Zero Tillage wheat in the rice-wheat systems have shown primarily positive impacts (Pandey et al., 2003) on wheat crop management, particularly through reduced input needs combined with potential yield increases. Hobbs and Gupta (2003) also supported that Zero Tillage technique reduced input needs for wheat production. Due to the adoption of ZT technology, the number of field operations for wheat crop establishment (including tillage) decrease from an average of seven to only one (Malik et al., 2002a). Effects on soils, weeds, pests and diseases in ZT typically improves soil quality in various dimensions, including soil structure, soil fertility and soil biological properties. ZT typically reduces the incidence of weeds in the wheat crop (Malik et al., 2002a); (Malik et al., 2002b). In fact, ZT reduced the nematodes population and enhanced both the earthworm population and predator diversity and density in wheat (Malik et al., 2002a); (Malik et al., 2002b).

Therefore, utilisation of high yielding genotypes, with mid-range of adaptability to edaphic and environmental conditions is very essential to increase yield per hectare and utilization of zero tillage method for sowing of wheat to increase yield per hectare. Keeping this in view, the present study was therefore, designed to determine the effect of zero tillage method and response of high yielding variety (HD 1563) on yield of wheat and economics of wheat cultivation.

\section{Materials and Methods}

The trial was carried out during Rabi season on 20 farmer's field of Pandarak, Ghoshwari and Barh Block in Patna district with size of trial in 20 acre. The machine Zero till seed cum fertilizer drill was provided by Krishi Vigyan Kendra, Barh, Patna. The farmers were selected on the basis of their past experience. Before trial training was conducted to farmers about use of Zero till seed cum fertilizer drill machine by the KVK scientists. Yield effects, cost savings and profitability, socio-economic and method impacts were study on above trial.

Wheat varieties were sown by broadcasting method as per treatment scheduled. The recommended basic full dose of $\mathrm{P}, \mathrm{K}$ and half dose of nitrogen as basal and the remaining nitrogen was applied in 2 equal doses, half at tillering and the rest half at boot stage. The sources of nutrients were urea, single super phosphate and muriate of potash for N, P and $\mathrm{K}$, respectively. The recommended dose of

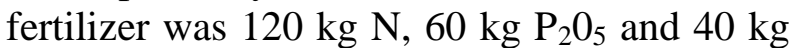
$\mathrm{K}_{2} \mathrm{O}$ per hectare. The crop was sown in the field using a seed rate of $120 \mathrm{~kg} / \mathrm{ha}$ by broadcasting method and in ZT method 100 $\mathrm{kg} / \mathrm{ha}$.

Keeping in the view need, under wheat cultivation area to increase area for research varieties for wheat cultivation in the district therefore Krishi Vigyan Kendra Barh, Patna has taken following technologies i.e. Promotion of short duration varieties of wheat, 
Promotion of research varieties of wheat (HD 1563) and Use of Zero Tillage method (ZT) for sowing of Wheat, intervention by front line demonstration.

\section{Results and Discussion}

Grain yield of wheat crop is the result of combined effect of various yield contributing components. It is evident from the data that high yielding variety (HD 1563) affected the grain yield. Maximum grain yield (35.8 q/ha) was obtained when wheat was sown by use of HD 1563 with minimum grain yield (32.9 $\mathrm{q} / \mathrm{ha}$ ). Maximum grain yield (23.90 q/ha) was obtained when wheat was sown by use of local wheat variety with minimum grain yield (16.61 q/ha). Average grain yield (34.1 q/ha) was obtained when wheat was sown by use of HD 1563 and Average grain yield (27.9 q/ha) was obtained in case of local wheat variety, under field trials of 15 farmers.

The cultivar HD 1563 recorded \% increase in yield was 20.8 as compared to local wheat variety. The variety HD 1563 recorded higher gross return $(52546.7 \mathrm{Rs} / \mathrm{ha})$ and net return (19590.0 Rs/ha) as compared to local variety having gross return (49286.7 Rs/ha) and net return (14034.7 Rs/ha). Gross cost for the cultivation of HD 1563 was $32956.7 \mathrm{Rs} / \mathrm{ha}$, in case of local variety gross cost was 35252.0 $\mathrm{Rs} /$ ha due to management practices. $\mathrm{B}$ : $\mathrm{C}$ ratio was also worked out for both farmers practice using HD 163 and local from sowing to harvesting as given in Table 1 .

The zero-tillage method is not remunerative but also eco-friendly. It envisages 100 per cent saving in land preparation as wheat sowing is done just after harvesting of preceding rice crop without any ploughing. Thus in zero tillage the soil is left undisturbed from harvest of rice to sowing of wheat. The data collected from the field were analyzed and the results of the study in respect of (i) Percentage increase in yield of HD 1563 with ZT and (ii) Economics and Benefit Cost ratio of HD 1563 with ZT are summarized in Table 2.

Percentage increase in yield: the yield in HD 1563 with ZT increased $33.9 \%$ over local variety. The average yield in HD 1563 With Zero tillage method was recorded $36.6 \mathrm{q} / \mathrm{ha}$ over local variety it is $27.4 \mathrm{q} / \mathrm{ha}$. The difference of yield in HD 1563 with ZT and without ZT with local variety is justified in Table 2.

Table.1 Yield and Economics of HD 1563 as compared to Local variety of wheat

\begin{tabular}{|c|c|c|c|c|c|c|c|c|c|c|c|}
\hline \multirow[t]{2}{*}{ SI No } & \multicolumn{2}{|c|}{ Yield (q/ha) } & \multirow[t]{2}{*}{$\%$ Increase } & \multicolumn{4}{|c|}{ Economics of HD-1563 (Rs/ha) } & \multicolumn{4}{|c|}{ Economics of Local variety (Rs/ha) } \\
\hline & $\begin{array}{c}\text { HD } \\
1563\end{array}$ & Local & & Gross cost & $\begin{array}{l}\text { Gross } \\
\text { Return }\end{array}$ & Net Return & $\begin{array}{c}* * \\
\text { BCR }\end{array}$ & Gross cost & $\begin{array}{l}\text { Gross } \\
\text { Return }\end{array}$ & Net Return & $\begin{array}{c}* * \\
\text { BCR }\end{array}$ \\
\hline 1 & 34.2 & 25.3 & 17.80 & 32400 & 52200 & 19800 & 1.61 & 34200 & 48800 & 14600 & 1.43 \\
\hline 2 & 33.2 & 26.8 & 23.88 & 33100 & 53000 & 19900 & 1.60 & 35600 & 49200 & 13600 & 1.38 \\
\hline 3 & 32.9 & 27.3 & 20.51 & 32450 & 51900 & 19450 & 1.60 & 34400 & 47900 & 13500 & 1.39 \\
\hline 4 & 33.7 & 27.8 & 21.22 & 34100 & 52600 & 18500 & 1.54 & 36600 & 48400 & 11800 & 1.32 \\
\hline 5 & 35.8 & 28,7 & 19.86 & 32500 & 52500 & 20000 & 1.62 & 34200 & 49300 & 15100 & 1.44 \\
\hline 6 & 33.6 & 27.8 & 20.86 & 33200 & 53200 & 20000 & 1.60 & 35700 & 49700 & 14000 & 1.39 \\
\hline 7 & 34.7 & 28.5 & 21.75 & 32700 & 53700 & 21000 & 1.64 & 34500 & 50300 & 15800 & 1.46 \\
\hline 8 & 35.8 & 30.7 & 16.61 & 32900 & 52800 & 19900 & 1.60 & 36000 & 48800 & 12800 & 1.36 \\
\hline 9 & 34.2 & 28.4 & 20.42 & 33100 & 51900 & 18800 & 1.57 & 36300 & 49700 & 13400 & 1.37 \\
\hline 10 & 33.8 & 29,7 & 23.90 & 32400 & 52700 & 20300 & 1.63 & 34400 & 49900 & 15500 & 1.45 \\
\hline 11 & 34.3 & 28.8 & 19.10 & 33150 & 52000 & 18850 & 1.57 & 35700 & 48800 & 13100 & 1.37 \\
\hline 12 & 33.5 & 27.3 & 22.71 & 32600 & 52300 & 19700 & 1.60 & 36200 & 50100 & 13900 & 1.38 \\
\hline 13 & 33.6 & 27.3 & 23.08 & 32800 & 51700 & 18900 & 1.58 & 34780 & 48750 & 13970 & 1.40 \\
\hline 14 & 34.2 & 28.7 & 19.16 & 33400 & 52600 & 19200 & 1.57 & 35500 & 49350 & 13850 & 1.39 \\
\hline 15 & 33.6 & 27.6 & 21.74 & 33550 & 53100 & 19550 & 1.58 & 34700 & 50300 & 15600 & 1.45 \\
\hline Average & 34.1 & 27.9 & 20.8 & 32956.7 & 52546.7 & 19590.0 & 1.6 & 35252.0 & 49286.7 & 14034.7 & 1.40 \\
\hline
\end{tabular}


Table.2 Yield and Economics of HD 1563 with ZT as compared to Local variety of wheat

\begin{tabular}{|c|c|c|c|c|c|c|c|c|c|c|c|}
\hline \multirow[t]{2}{*}{ SI No } & \multicolumn{2}{|c|}{ Yield (q/ha) } & \multirow{2}{*}{$\begin{array}{c}\% \\
\text { Increas } \\
\text { e }\end{array}$} & \multicolumn{4}{|c|}{ Economics of HD-1563 with ZT (Rs/ha) } & \multicolumn{4}{|c|}{ Economics of Local variety (Rs/ha) } \\
\hline & $\begin{array}{c}\text { HD } \\
1563 \\
\text { with ZT }\end{array}$ & $\begin{array}{c}\text { Loca } \\
\quad 1\end{array}$ & & $\begin{array}{c}\text { Gross } \\
\text { cost }\end{array}$ & $\begin{array}{c}\text { Gross } \\
\text { Return }\end{array}$ & $\begin{array}{c}\text { Net } \\
\text { Return }\end{array}$ & $\begin{array}{c}* * \\
\text { BCR }\end{array}$ & $\begin{array}{c}\text { Gross } \\
\text { cost }\end{array}$ & $\begin{array}{c}\text { Gross } \\
\text { Return }\end{array}$ & $\begin{array}{c}\text { Net } \\
\text { Return }\end{array}$ & $\begin{array}{c}* * \\
\mathbf{B C R}\end{array}$ \\
\hline 1 & 36.4 & 27.8 & 30.94 & 33800 & 54500 & 20700 & 1.61 & 35100 & 51300 & 16200 & 1.46 \\
\hline 2 & 35.7 & 25.2 & 41.67 & 32900 & 54400 & 21500 & 1.65 & 34800 & 52100 & 17300 & 1.50 \\
\hline 3 & 36.9 & 28.4 & 29.93 & 32600 & 52700 & 20100 & 1.62 & 33900 & 49800 & 15900 & 1.47 \\
\hline 4 & 36.7 & 26.9 & 36.43 & 31600 & 53000 & 21400 & 1.68 & 34600 & 48800 & 14200 & 1.41 \\
\hline 5 & 37.5 & 28.7 & 30.66 & 32900 & 52800 & 19900 & 1.60 & 34800 & 49300 & 14500 & 1.42 \\
\hline $\begin{array}{l}\text { Aver } \\
\text { age }\end{array}$ & 36.6 & 27.4 & 33.9 & 32760.0 & 53480.0 & 20720.0 & 1.6 & 34640.0 & 50260.0 & 15620.0 & 1.45 \\
\hline
\end{tabular}

Benefit Cost ratio: B: C ratio (BCR) were also worked out for both HD 1563 with ZT and local variety from sowing to harvesting as given in Table 2 . The $\mathrm{B}$ : $\mathrm{C}$ ratio as observed from table has been more in HD 1563 with ZT field as compare to local variety of sowing of wheat. It is because of reduction in primary tillage operation in ZT method as well as due to higher production. Verma et al., (2017) also supported that zero-tillage method is superior as compared to conventional method sowing of wheat.

The average yield in HD 1563 with ZT was recorded $36.6 \mathrm{q} /$ ha (Table 2) over HD 1563 sowing it is $34.1 \mathrm{q}$ ha-1 (Table 1). The data collected from the field were analyzed and the result of the study in respect of percentage increase in yield in HD 1563 with ZT increased $7.33 \%$ over farmers practice by using HD 1563 without ZT. From the economic point of view HD 1563 with ZT was recorded (Rs.20720.0/ha) higher net return as compared to HD 1563 without ZT (Rs.19590.0/ha). Rawat and Varma (2006) also supported that zero tillage is that it reduces the cost of cultivation which was more economical in comparison to conventional method of sowing.

It is concluded from the results of the experiment that in order to get maximum yield of wheat variety HD 1563 was found to be more suitable variety as compared to local variety. HD 1563 with ZT can also be recommended for higher yield of wheat in Patna district of Bihar.

\section{References}

Anonymous. 2011. Annual Report 2011-12, Department of Agriculture and Cooperation, Ministry of Agriculture, Government of India, 2011.

Anonymous. 2015. Progress Report 2014-15. All India Coordinated Wheat and Barley Improvement Project, Directorate of Wheat Research, Karnal.

Dabre, W. M., Lall, S. B. and Lngole, G. L. 1993. Effects of sowing dates on yield, ear number, stomatal frequency and stomatal index in wheat. $J$. Maharashatra Agri. Univ. 18: 64-66.

FAO. 2011. Crop Prospects and Food Situation. Global Information and Early Warning System, Trade and Markets Division, FAO, Rome.

Hobbs, P. R. and Gupta, R. K. 2003. Resource-conserving technologies for wheat in the rice- wheat system. In: J. K. Ladha, J. E. Hill, J.M. Duxbury, R. K. Gupta, and R.J. Buresh (eds.), Improving the Productivity and Sustainability of Rice-Wheat Systems: Issues and Impacts. ASA Special Publication Number 65. Madison, 
Wisconsin: ASA-CSSA-SSSA. 149172.

Malik, R. K., Balyan, R. S., Yadav, A. and Pahwa, S. K. (eds.). 2002a. Herbicide Resistance Management and ZeroTillage in Rice-Wheat Cropping System. Proceedings of International workshop, Chaudhary Charan Singh Haryana Agricultural University (CCSHAU), 4-6 March, 2002. Hisar, India.

Malik, R. K., Mehla, R. S. and Singh, B. K. 2002b. Conservation tillage technologies and farmers participatory research, extension approaches in Haryana- a case study. In: $R W C(e d$. Proceedings of the International Workshop on Developing an Action Program for Farm-level Impact in RiceWheat System of the Indo-Gangetic Plains, New Delhi, 25-27 September, 2000. RWC Paper Series 14. Rice-
Wheat Consortium of the Indo-Gangetic Plains, New Delhi, 31-45.

Pandey, L. M., Pal, S. and Mruthyunjaya. 2003. Impact of zero-tillage technology in the rice (Oryza sativa) - wheat (Triticum aestivum) system of foothills of Uttaranchal State, India. Indian Journal of Agricultural Sciences. 73: 432-437.

Rawat, S. N. and Varma, M. R. 2006. Performance Evaluation of Zero-till Ferti Seed-drill for Wheat Crop. Karnataka J. Agric. Sci. 19(2): 348-351.

Verma, P. D., Parmanand and Tamrakar, S. K. 2017. Comparison of Zero-tillage Technology and Traditional Techniques for Sowing of Wheat: Evidence from Farmers Field by Front line Demonstration. International Journal of Agriculture Innovations and Research. 5(6): 1016-1019.

\section{How to cite this article:}

Mrinal Verma, B.D. Singh, Prakash Chandra Gupta and Rajeev Kumar. 2018. Zero Tillage Technique with High Yielding Variety for Wheat Cultivation as Compared to Traditional Method of Farmers: Evidences of FLD. Int.J.Curr.Microbiol.App.Sci. 7(08): 2512-2516. doi: https://doi.org/10.20546/ijcmas.2018.708.255 